\title{
FILMES NAS AULAS DE HISTÓRIA
}

\section{Filme, de ficção ou documentário, é importante recurso pedagógico para o ensino de História}

Há um grande número de professores que se utilizam do filme como recurso didático no ensino de História. Alguns obtêm resultados significativos, enquanto outros acabam por não aproveitar todo o potencial que o cinema - e por extensão o vídeo - pode oferecer.

Tentarei através deste artigo relatar, a partir da minha experiência como professor de História, que utiliza a linguagem cinematográfica no processo ensino-aprendizagem, algumas dinâmicas de análise de filmes em vídeo, esclarecendo, na medida do possível, como, através de qualquer tipo de filme, pode se dar a produção do conhecimento histórico na sala de aula.

Quando se pensa em exibir um filme para alunos, com o intuito de mostrar o seu valor documental, logo vem à mente o gênero documentário, devido à suposta carga de veracidade que este possui. Mas, até que ponto podemos afirmar que o documentário é mais fidedigno quanto ao tema e ao período tratado do que o gênero ficcional? Será que trabalhando apenas com o documentário

\section{O AUTOR}

Antônio Reis Júnior

Professor de História da rede estadual de São

Paulo. Pesquisador na área de Comunicação e

Educação. estaremos diante da reprodução da realidade, enquanto o filme de ficção, por ter como objetivo maior o entretenimento, se cons-tituirá somente numa recriação fantasiosa?

É bom frisarmos que nenhum documento, seja ele qual for, reproduzirá a realidade tal qual ela é. Ele obrigatoriamente será uma representação. E aqui cabe o gênero documentário. Cinematograficamente, as formas de contar a História nos documentários são as mesmas formas de contar a ficção'.

\section{FICÇÃO OU DOCUMENTÁRIO}

Não é difícil perceber que no processo de escolha das imagens a realidade poderá ser costurada, já que, desde a filmagem, a escolha de umas imagens pressupõe sempre a exclusão de outras. Na montagem, mais uma vez, o que foi filmado passa por uma seleção e ordenação.

Neste processo entram também outros elementos cinematográficos que têm de ser levados em conta. O movimento da câmera, a trilha sonora, o uso de filtros, a entrevista são alguns elementos que compõem o alfabeto cinematográfico, responsáveis pela recriação/representação/ interpretação da realidade, sendo que cada um deles criará significações diversas, resultando na elaboração de um discurso. 
Portanto, o aparente status de documento privilegiado do documentário em relação ao filme de ficção não é adequado. Além disso, o filme de ficção seduz muito mais os alunos do que o gênero documentário ou o filme educativo, devido ao fato de existir o elemento do prazer proporcionado pelo cinema de espetáculo, ausente, na maioria das vezes, nos outros gêneros.

Mesmo não tendo comprometimento com a realidade, o gênero ficcional pode refletir de forma imediata a mentalidade de um povo, seus valores e comportamentos, estabelecendo uma relação direta entre o filme e o meio que o produz. Os cineastas não pretendem copiar a realidade mas, ao transferi-la para o filme, revelam todos os seus mecanismos ${ }^{2}$.

O filme sempre é uma testemunha do seu tempo, assim como a literatura, as artes plásticas e outras manifestações artísticas. Cabe ao professor desvendar todos esses mecanismos, tornando-se um espectador especializado, educando o seu olhar para com preender a especificidade da linguagen cinematográfica.

Partindo da idéia de que todo filme é histórico, na medida em que ele traz consigo informações, idéias e valores sobre o contexto social que o produziu ${ }^{3}$, isto é, levando em consideração que o filme pode estar mais repleto de informações sobre a época em que foi produzido do que sobre o período e o tema que tratou, caberá ao professor de História identificar essa dupla face. A primeira, que se constitui do conjunto de informações da sociedade que o gerou, e a se- gunda, que é a análise do processo de reconstituição histórica do tema tratado, esclarecendo de que forma se deu a leitura cinematográfica da História.

\section{O PAPEL DO PROFESSOR}

O professor deve trabalhar no sentido de dar transparência ao processo de construção da História na narrativa fílmica para poder analisar criticamente os conteúdos históricos dos filmes com seus alunos.

$\mathrm{O}$ que a imagem reflete? Qual o grau possível de manipulação da imagem? Como aparecem os trabalhadores, os negros, os artistas, os políticos e outros grupos na história do cinema? Com que olhos os diretores cinematográficos olharam o passado? Houve respeito pelo conhecimento histórico produzido pela Academia nestes filmes?

Todas essas perguntas devem ser feitas pelo professor durante sua análise, enfatizando que o filme de época será sempre um modo de representação do passado, condicionado pela linguagem cinematográfica.

Entretanto, a primeira leitura do filme deverá sempre ser feita pelo aluno para não haver o risco de influência de idéias por parte do professor. Ele não deve ser o primeiro a dar opinião nem tampouco monopolizar a discussão. Deve opinar e tomar partido sobre o filme no decorrer de sua ação, agindo como mediador do debate.

Marc Ferro, historiador francês pioneiro nos estudos da relação entre cinema e história, desperta para o fato de existir em todo o filme uma "realidade não-visível"4. Isto é, o filme acaba sempre excedendo seu

2. KORNIS, Mônica Almeida. História e Cinema: um debate metodológico. Estudos Históricos. Rio de Janeiro, v.5, n.10. 1992. p.237-250.

3. ROCHA. Antônio Penalves. O filme: um recurso didático no ensino da História? Lições de cinema. São Paulo: FDE. n.2. 1992.52p.

4. FERRO, Marc. Cinema e História. Rio de Janeiro: Paz e Terra, 1992. 143p. 
próprio conteúdo, revelando aspectos da realidade que ultrapassam o objetivo do realizador, além de, por trás das imagens, estar expressa a ideologia de uma sociedade. Dentro desta perspectiva é que se deve encarar o filme como um documento valioso para o historiador e também para o professor que deve identificar essa realidade não-visível presente na maioria dos filmes.

A utilização de curtas-metragens é a mais indicada para o uso em sala de aula, já que a projeção de um longa-metragem tem em média 120 minutos, pode ser inviável por exceder o espaço de tempo de uma aula que tem em média 50 minutos.

O critério de escolha dos filmes deverá levar em conta a faixa etária da classe, adequando a capacidade de entendimento dos alunos e a natureza da matéria. $\mathrm{O}$ uso de textos concomitante ao uso de filmes é fundamental.

Algumas vezes um filme acaba por apresentar apenas como pano de fundo o tema que se deseja discutir. Desta forma, sua

Resı no: $\mathrm{O}$ artigo trata do uso didático do filme r 0 ensino de História. A distinção entre filme documentário e filme de ficção não é o fator determinante para o seu aproveitamento em sala de aula. O fundamental é que o professor saiba por quê e como usar o filme adequadamente.

Palavras-chave: cinema, filme, ensino, História, didático utilidade residirá no fato de ele ser dinamizador de uma discussão. Ou seja, o filme dará apenas o pontapé inicial do debate deste mesmo tema ou do período tratado na obra.

Existe uma natureza pedagógica nas linguagens audiovisuais e todo e qualquer filme pode ser educativo a partir do momento em que o professor se aproprie dele de forma didática.

Porém, compreender o processo de construção do filme implica uma complexa análise de dados que vão desde a produção industrial do filme, passando pelo domínio da linguagem, até a compreensão de como a história é construída no interior da narrativa fílmica5.

Cabe ao professor, dentro das condições de trabalho que se oferecem hoje em nossas escolas, enfrentar esse desafio junto a seus alunos que, assim como nós, fazem parte de uma geração cada vez menos escrita e cada vez mais audiovisual.

Abstract. This article deals with the didactic use of motion pictures in teaching History. The difference between documentary films and fictional ones is not the determining factor for its utilization in the classroom. It is more important that the teacher possess the necessary basic knowledge to take full advantage of this audio-visual resource.

Key-words: cinema, video, teaching, History, didactic

5. SALIBA, Elias Thomé. A produção do conhecimento histórico e suas relações com a narrativa fílmica. Lições de cinema. São Paulo: FDE, n.3, 1992. 80p. 